\title{
THE LEGAL STATUS OF THE ATTORNEY GENERAL'S "LIST"
}

The Deportation and Exclusion Laws of 1917,1918 , and $1920^{1}$ forbade the admission of alien members of organizations which advocated the overthrow of the Government of the United States by force or violence. Faced with the necessity of deciding which organizations followed this pohicy, Attorney General A. Mitchell Palmer listed 12 organizations, membership in which would automatically lead to exclusion or deportation for alien members. ${ }^{2}$ However, the deportation proceedings instituted under the acts aroused such a public clamor that the list, as a standard, was withdrawn. ${ }^{3}$

After the rise of Hitler, the various congressional committees on un-American activities histed organizations deemed dangerous to the United States. ${ }^{4}$ With the passage of section $9 \mathrm{~A}$ of the Hatch Act, ${ }^{5}$ which denied federal employment to persons who belonged to groups advocating the violent overthrow of the Government, and the Voorhis Anti-Propaganda Act, ${ }^{\circ}$ requiring the registration with the Attorney General of such groups, the need for a criterion became apparent. ${ }^{7}$ This became especially true when a rider to the Department of Justice Appropriations Act $^{8}$ was passed giving the Attorney General $\$ 100,000$ for investigating federal employees who belonged to "subversive" organizations. The Attorney General ruled that "subversive" was to be equated with advocacy of the violent overthrow of the Government and submitted a list of such organizations. ${ }^{\circ}$ President Roosevelt issued Executive Order No. $9300,{ }^{10}$ which set up a committee within the Justice Department to deal with subversive activity of federal employees. Apparently recourse was had to the Attorney General's list by the committee. ${ }^{11}$ This list was not made pubhic in its entirety until 1947.

In 1947 President Truman signed Executive Order No. $9835,{ }^{12}$ which granted to the Attorney General the power to declare organizations subversive after an "appropriate investigation and determination."13

Apparently without notifying any of the organizations imvolved, ${ }^{14}$ the Attorney General then compiled and disseminated a list of the organizations he considered

I 39 STar. 874 (1917); 40 STaT. 1012 (1918), 8 U.S.C. § 137 (1952); 41 STaT. 1008 (1920), 8 U.S.C. $\$ 137$ (1952).

2 Attorney General A. Mitchell Palmer on Charges Against the Department of Justice by Louis F. Post and Others, Hearings Before the House Committee on Rules, 66th Cong., 2d Sess., pt. 1, at 14 (1920). This list was never made public but was used by the Department of Labor in immigration and deportation proceedings.

3 Bontecou, The Federal Loyaity-Security Program 163-64 (1953). See also Colyor v. Skeffington, 265 Fed. 17 (D. Mass. 1920), where Judge Anderson excoriated the system of deportation althougl uplolding one of the Administrative decisions before lim.

4 House Special Committee on Un-American Activities, Investigation of Nazi and Other Propaganda, H.R. REP. No. 121, 74th Cong., 1st Sess. (1935); House Special Committee on Un-American Activities, Report on Congress of Industrial Organizations, Political Action Committee, H.R. REP. No. 318, 78th Cong., 2d Sess. 186 (1944).

553 STaT. 1148 (1939), 5 U.S.C. \$ 118 (1952).

654 STaT. 105 (1940), 5 U.S.C. $\$ 790$ (1952).

7 Bontecou, The Federal Lofalty-Security Program 164 (1953).

855 STAT. 289, 292 (1941), 41 U.S.C. \$ 6 (1952).

9 H.R. Doc. No. 883, 77th Cong., 2d Sess. 27 (1942).

108 FED. REg. 1701 (1943).

11 Note, 29 TeMr. L.Q. 95 (1955).

1212 FED. REc. 1935 (1947).

13 Exec. Order No. 9835, Part III (3), 12 FED. REg. 1935 (1947).

14 See Joint Anti-Fascist Refugee Committee v. McGrath, 341 U.S. 123, 126 (1951). 
either "totalitarian," "fascist," "communist," "subversive," or "which advocate the overthrow of the Government of the United States by force and violence."15 Included on this list were groups which liad been previously listed ${ }^{16}$ as well as other organizations designated for the first time. In the list published in March $1948^{17}$ all the groups were designated in alphabetical order without any attempt to categorize them in relation to the categories set up in Executive Order No. 9835. ${ }^{18}$ In September 1948 a new list was published which labeled 21 groups as "totalitarian," 15 as "fascist," 4 as "having adopted a policy of force and violence to deny others their constitutional rights," 5 as "seeking to alter the form of Government of the United States by unconstitutional means," and 6 as "subversive."19 Subsequent designations ${ }^{20}$ adhered to these labels until Augnst 1953 when without explanation a consolidated list was again published without categorization. ${ }^{21}$

\section{POSITION OF THE IISTED GROUPS}

Among the groups first designated in May 1948 was the Joint Anti-Facist Refugee Committee, ostensibly a "charitable organization engaged in relief work."22 This group brought action for declaratory and injunctive relief against the Attorney General. Relief was ultimately granted by the Supreme Court ${ }^{23}$ on the ground that the conduct of the Attorney General was either "patently arbitrary" or a denial of due process. ${ }^{24}$ Since the listing of the Committee without a learmg was not a "determination" as required by the Order, ${ }^{25}$ the Attorney General was said to have exceeded his authority.

Subsequently Executive Order No. 9835 was repealed, ${ }^{26}$ but the power granted to the Attorney General was restated by Executive Order No. $10450^{27}$ issued by President Eisenhower. Thereafter the Attorney General issued rules of procedure which generally prescribed notice and hearing for groups the Justice Department proposed to designate as subversive. ${ }^{28}$ The regulations expressly provided that previous designations were not affected and that they would continue in effect unless the procedures outlined were followed by the groups previously listed. ${ }^{29}$ The

15 The list was published (Statement of the Loyalty Review Board, 13 FED. REg. 1471, 73 (1948)) by the Loyalty Review Board, which had also been established by Exec. Order No. 9835, Part III (1), 12 FED. REG. 1935 (1947), and whose duty it was to review cases involving persons recommended for dismissal on grounds relating to loyalty by the loyalty board of any department or agency and to make advisory recommendations thereon.

16 See notes 2 and 9 supra.

17 Statement of the Loyalty Review Board, 13 FED. REg. 1471, 1473 (1948).

1812 FED. REg. 1935 (1947).

10 This list was also published by the Loyalty Review Board. Statement of the Loyalty Review Board, 13 FED. REg. 6135 (1948).

20 Statements of the Loyalty Review Board, 15 FED. REG. 8145 (1950), 16 FED. REG. 12214 (1951).

21 18 FED. REg. 2741 (1953). This list was published by the Attorney General's Office, the Loyalty Review Board having become defunct. Exec. Order No. 10450, 18 FEd. REg. 2489 (1953).

22 This was the description given by Justice Burton in Joint Anti-Fascist Refugee Committee v. McGrath, 341 U.S. 123, 130 (1951).

23 Joint Anti-Fascist Committee v. McGrath, 341 U.S. 123 (1951).

24 See text at note 131 infra.

25 Exec. Order No. 9835, pt. III (3), 12 FED. REg. 1935 (1947).

20 Exec. Order No. 10450, (12), 18 FED. REg. 2489 (1953).

27 Id. at (13).

2828 C.F.R. pt. 41 (Supp. 1955).

2028 C.F.R. \$ 41.11 (Supp. 1955). 
procedures require written notice from the organization that it wishes to contest the designation. ${ }^{30}$

In 1953 the Attorney General advised the National Lawyers Guild that he proposed to designate the Guild as an organization under the purview of Executive Order No. 10450.31 The Guild filed for injunctive rehef, contending that the Executive Orders ${ }^{32}$ were unconstitutional and that the procedural regulations denied the Guild due process of law.

The Court of Appeals for the District of Columbia ${ }^{33}$ questioned some features of the regulations: elimination of oral testimony and cross-examination, ${ }^{34}$ the complete elimination of evidence in the discretion of the Attorney General, ${ }^{35}$ and making an "evasive" reply to an interrogatory an "admission" of the facts to which the interrogatory referred. ${ }^{36}$ However, Judge Prettyman, speaking for the court, declared that the rules permitted a valid proceeding, including the basic tests of notice and liearing. ${ }^{37}$ The court would not speculate in advance as to the details of a proceeding yet to be held and ruled that the Guild was therefore required to exhaust the administrative remedies set forth in the regulations before application for relief to the courts. ${ }^{38}$

The court also stated that the decision in Joint Anti-Fascist Committee v. $M c G r a t h^{39}$ turned upon the lack of procedural safeguards for the organization designated and that "implicit in [the Supreme Court's] opinion is the premise

3028 C.F.R. $\$ 41.1$ (b) (Supp. 1955) reads as follows: "(b) Whenever the Attorney General after appropriate investigation proposes to designate an organization pursuant to Executive Order No. 9835 or Executive Order No. 10450, or both, notice of such proposed designation shall be sent by registered mail to such organization at its last known address. If the registered notice is delivered, the organization, within ten days following its receipt or ten days following the effective date of Executive Order No. 10450, whichever shall be later, may file with tho Attorney General, Department of Justice, Washington, D.C., a written notice that it desires to contest such designation. If the notice of proposed designation is not delivered and is returned by the Post Office Department, the Attorney General shall cause such notice to be published in the Federal Register, supplemented by such additional notice as the Attorney General may deem appropriate. Within thirty days following such publication in the Federal Register, such organization may file with the Attorney General, Department of Justice, Washimgton, D.C., a written notice that it desires to contest such designation. Failure to file a notice of contest within such period shall be deemed an acquiescence im such proposed action, and the Attorney General may thereupon after appropriate determination designate such organization and publish such designation in the Federal Register."

3118 FED. REg. 2489 (1953).

32 Exec. Order No. 9835, 12 Fed. REg. 1935 (1947); Exec. Order No. 10450, 18 Fed. Reg. 2489 (1953).

33 National Lawyers Guild v. Brownell, 225 F.2d 552 (D.C. Cir. 1955).

3428 C.F.R. \$ 41.8(f) (Supp. 1955). "In the discretion of the board or officer, the affidavit of any witness may be received in lieu of his oral testimony." Ibid.

3528 C.F.R. \$ 41.8(a) (Supp. 1955). "If upon the basis of the statement, imterrogatories, reply and affidavits (if any) submitted as provided in this part it appears to the board or hearing officer that a determination may appropriately be made without the taking of evidence, the proceeding may be conducted without the taking of such evidence." Ibid.

3628 CF.R. \$ 41.3 (Supp. 1955). "The submission of an evasive reply to any interrogatory or any part thereof shall likewise be deemed an admission of the facts to which tho interrogatory or part thereof refers." Ibid.

37 National Lawyers Guild v. Brownell, 225 F.2d 552, 556 (D.C. Cir. 1955).

$38 \mathrm{Id}$. at 557 .

39341 U.S. 123 (1951). 
that the listings were not invalid for total lack of power in the President and the Attorney General."40

Since the issuance of the procedural rules there has been no court test of a final administrative designation. Whether the application of these rules in a particular case affords due process must await such a final determination and a resultant court test. However, it is important to note that the Attorney General has discontinued the classification of organizations as "totalitarian," "fascist," "communist," etc., and lias grouped them alphabetically without reference to any particular category. ${ }^{41}$ The abolition of the distinctions among organizations would seem to curtail the value and efficacy of the list, since many statutes which proscribe meinbership in certain orgamzations refer to "subversive" 42 groups or to groups which "advocate the overthrow of the government by force and violence" mention of "fascist" groups or of the other categories of organizations which the Attorney General was instructed to designate. ${ }^{44}$

In spite of the decision in Joint Anti-Fascist Refugee Committee v. McGrath in 1951, the Attorney General in April 1953 under the authority of Executive Order No. $10450,{ }^{45}$ redesignated the organizations which had been previously designated under Executive Order No. $9835{ }^{46}$ Since there was no hearing prior to redesignation, the regulations providing for a learing were of no aid to the groups designated at that time and their status as cited organizations lias continued to the present time. Assistant Attorney General William F. Tompkins, in charge of the Internal Security Division, reported that final arrangements had been made in June 1955 for the first hearings under the regulations promulgated in May 1953.47 In the meantime, all organizations previously designated have remained on the list

40 National Lawyers Guild v. Brownell, 225 F.2d 552, 556 (D.C. Cir. 1955). There were six opinions in Joint Anti-Fascist Refugee Committee v. McGrath, 341 U.S. 123 (1951). See text at note 131 infra. The judgment of the Court was announced by Justice Burton with whom Justice Douglas concurred. Justice Burton said, "If, upon the allegations in any of these complaints, it had appeared that the acts of the respondents, from which relief was sought, were authorized by the President under his Executive Order No. 9835, the case would have bristled with Constitutional issues. On that basis the complaint would have raised questions as to the justiciability and merit of claims based upon the First, Fifth, Nimth and Tenth Amendments to the Constitution. It is our obligation, however, not to reach those issues unless the allegations before us squarely present them." 341 U.S. at 135. Justice Black, concurring, said, "Assuming, though I deny, that the Constitution permits the executive officially to determine, list and publicize individuals and groups as traitors and public enemies . . ." 341 U.S. at 143. Justice Frankfurter also concurring, dealt mainly with the due process issue but did compare the situation to the one which gave rise to the Sedition Act of 1798, 1 Stat. 596 (1798). The remaining concurring opimions of Justices Douglas and Jackson also dealt with the due process issue. The three dissenting Justices (Reed, Minton and Vinson) argued that the President had the power to direct the Attorney General to issue the list and that the procedure did not deny appellants due process of law.

41 Compare the list published by the Loyalty Review Board in December 1951, 16 FED. REG. 12214 (1951), with the list published by the Attorney General in May 1953, 18 FED. REG. 2741 (1953).

42 Pa. Stat. Ann. tit. 18, §3811 (Purdon, Supp. 1954); Utan Code Ann. \$\$ 27-11-11, 27-11-15(b) (1953).

4353 StaT. 1147 (1939), 5 U.S.C. § 118 (1952); Miss. Code ANN. § 8610-18 (Supp. 1952);

N. C. Gen. Stat. AnN. \$ 14-12.1.

44 Exec. Order No. 9835, pt. III (3), 12 FEb. REg. 1935 (1947).

45 Exec. Order No. 10450, 18 FED. REg. 2849 (1953).

46 Exec. Order No. 9835, 12 FED. REg. 1935 (1947).

47 Atr'y Gen. ANN. REP. 57 (1955). 
without any hearing despite the ruling by the Supreme Court in 1951 that such action was "patently arbitrary." 48

Another serious weakness in the compilation of the list is the fact that 117 of the organizations designated in 1953 are defunct and hence cannot protest the designation as provided in the Attorney General's regulations. ${ }^{40}$ As a result they continue on the list and presumably their former members are subject to any sanctions which may be imposed because of membership despite the fact that no hearing was given to the organizations involved.

\section{EFFECT OF MEMBERSHIP IN A IISTED ORGANIZATION}

\section{Employment}

\section{The Federal Employees' Security Program ${ }^{50}$}

At the present time the most publicized impact of the Attorney General's list would appear to be in the field of federal employment, both as to present employees and to applicants for federal jobs. As stated by Justice Douglas, "A disloyalty trial is the most crucial event in the life of a public servant."

In Executive Order No. $10450^{52}$ the lieads of all agencies are directed to

develop information as to whether the employment or retention of employment in federal service of the person being investigated is clearly consistent with the interests of national security, ${ }^{53}$ [and] that such information shall relate but not be bimited to ... membership in, or affitiation or sympathetic association with any forcign or domestic organization, association, movement, group, or combination of persons [which is] totalitarian, fascist, communist, or subversive, or [which has] adopted or [which] shows, a policy of advocating or approving the commission of acts of force or violence to deny others their rights under the Constitution of the United States or which seeks to alter the form of Government of the United States by unconstitutional means. ${ }^{64}$

Under this order the Attorney General submits his list to the lieads of all agencies of the federal government for their consideration in determining whetler the retention in employment of a present or prospective employee is "consistent with the best interests of national security." The now defunct Loyalty Review Board promulgated regulations which stated that affiliation with any of the organizations on the Attorney General's list was merely evidence, and that "American ideas of justice do not include gnilt by association." that past or present membership in one of these groups is sufficient ground for summary suspension of the employee by the liead of the department. ${ }^{56}$

48 Jomint Anti-Fascist Refugee Committee v. McGrath, 341 U.S. 123, 137 (1951).

4928 C.F.R. § 41.1(b) (Supp. 1955). See note 30 supra.

50 Established by Exec. Order No. 10450, 18 FED. REg. 2489 (1953). See Mankiewicz, Mangum, \& Moody, The Federal Loyalty-Security Program; A Proposed Statute, 44 Carrr. L. Rev. 72 (1956).

51 Joint Anti-Fascist Refugee Committee v. McGrath, 341 U.S. 123, 180 (1951).

5218 FED. REg. 2849 (1953).

53 Exec. Order No. 10450, (5), 18 FEd. Reg. 2849 (1953).

54 Id., (8) (a) (5). Part III (3), 12 FED. REG. 1935 (1947), directed the Attorney General to designate " . . . each foreign or domestic organization, association, movement, group, or combination of persons [which is] totalitarian, fascist, communist, or subversive, or [who have] adopted a policy of advocating or approving the commission of acts of force or violenco to deny others their rights under the Constitution of the United States or which seeks to alter the form of Government of the United States by unconstitutional means."

55 Statement of the Loyalty Review Board, 13 FED. REg. 1471 (1948).

56 Yarmolinsky, Case Studies in Persgnnel Security, Case Nos. 18, 20, 23, 37, (1955). 
A recent study of personnel security cases indicates that at least a substantial portion of the charges against the employee are based upon past membership in or affiliation with listed groups..$^{57}$

\section{State Programs for Employees}

Many states and municipalities have adopted laws and ordinances requiring oaths or affidavits of "loyalty" from public employees. Some of these refer to the Attorney General's list specifically, ${ }^{58}$ but the majority proscribe past or present membership in "subversive" organizations. ${ }^{59}$ There is considerable evidence that the list is being used as a guide for the definition of "subversive organization" by officials charged with administering the various state programs. ${ }^{60}$

In Arizona employees of state and county welfare boards will be paid salaries only when they sign an affidavit stating that they are not now and have not been for the past three years a member of any organization on the Attorney General's List. ${ }^{61}$ A Louisiana statute provides that no person may hold any non-elective position in the government of the state or any political subdivision thereof wliere the evidence shows such person to be a "knowing member" of an organization listed by the United States Department of Justice. ${ }^{62}$ Newark, New Jersey, ${ }^{63}$ and New York City" as well as the state of New York" have passed "loyalty oath" requirements for teachers and other public employees which contain questions concerning such membership. ${ }^{66}$

In Wieman v. Updegraff ${ }^{67}$ a unanimous Supreme Court struck down an Oklahoma statute which required the signing by state employees of an affidavit of nonmembership for the past five years in any organization designated by the Attorney General. ${ }^{23}$ In this case the Court held that denial of employment on the basis of mere past or present membership in an organization without knowledge of its subversive objectives "must fall as an assertion of arbitrary power."

\footnotetext{
67 Ibid.

58 Aruz. Code AnN. \$ 70-138 (Supp. 1949) ; LA. Rev. Stat. ANw. \$§ 14, 359, 362, (1954); N.Y. UNCoNsolmated Laws § 1108 (McKinney 1955); OKIA. STat. ANw. tit. 51, §§ 36.2, 37.137.8 (Supp. 1954). Oklahoma's original law, OKrA. STAт. tit. 51, §37.2 (1951), was declared violative of due process in Wiemann v. Updegraff, 344 U.S. 183 (1952), and was re-enacted in its present form in 1954.

60 Ata. Code AnN. tit. 14, § 97 (7) (Supp. 1949); Ark. Stat. ANN. §§ 41-4111, 41-4113 (1947) ; Cat. Const. art. 20, § 3; CaI. Govt. Code §§ 3102, 3103 ; Fra. Stat. ANw. \$§ 876.05876.10 (1955).

60 See the testimony of Norman J. Small, Professor of Law at the Catholic University of America, in Hearings Before the Sub-committee on Constitutional Rights of the Senate Committee on the Judiciary, 84th Cong., 2d Sess., at 249-96 (1956).

61 ARtz. CODE ANN. \$ 70-138 (Supp. 1952).

62 La. Rev. Stat. ANN. \$§ 14:359, 362 (1954).

63 N.Y.Times, June 1, 1955, \& 1, p. 6, col. 3.

64 N.Y.Times, Dec. 11, 1953, §1, p. 9, col.1.

65 N.Y.Times, June $1,1955, \S 1$, p. 6 , col. 3 .

60 There are many states and mumicipalities which require the registration with the state or city police of members of organizations cited by the Attorney General. Der. CodE ANN. $\S \S 19: 3501-3502$ (Supp. 1954); MTcr. Stat. ANn. §§ 28,243(11)-28,243(22) (Supp. 1953); New Rochelle, N.Y., lias also passed this type of ordinance. N.Y. Herald Tribune, Sept. 19, 1950, p.3, col. 7 .

67344 U.S. 183 (1952).

68 OkIA. STAT. tit. 51, \$37.2 (1951).

${ }^{69}$ Wiemann v. Updegraff, 344 U.S. 183, 192 (1952), The Supreme Court, 1952 Term, 67 Harv. L. Rev. 91, 97 (1953); 22 U. Cin. L. Rev. 243 (1953).
} 
However, Adler v. Board of Education ${ }^{70}$ and Gerende v. Board of Supervisors of Elections ${ }^{71}$ had previously upheld loyalty oaths with similar provisions required of school teachers and candidates for public office. In Wieman, the court distinguished these cases by stating that the oaths required in Adler and Gerende imphed knowledge on the part of the teacher or candidate of the character and objectives of the organization.

The statutes in Adler and Gerende proscribe past or present membership in subversive organizations. Hence, any use of the Attorney General's list by state officials in administering these or similar programs can be criticized on two grounds. First, since the Attorney General's list is no longer broken down into the original categories, in order to determine what each organization stands for, a new investigation by the official using the list is required. Secondly, aside from the foregoing objection, smce the Attorney General's original action in listing the groups was either "patently arbitrary" or a denial of due process, ${ }^{72}$ and since as to organizations previously listed all that was done was to relist them without any hearing, the list is of doubtful validity at least as to those organizations.

\section{The Industrial Security Program}

The Secretary of Defense has issued regulations ${ }^{73}$ which require that every classified contract granted by the Department of Defense or the individual armed services contain a clause requiring the contractor to suspend or refuse to employ on that contract any person not cleared by the service concerned with the contract. ${ }^{74}$ The individual armed services have promulgated regulations concerning the clearance of employees working on classified contracts. ${ }^{75}$ These regulations provide for the accomplishment of a Personnel Security Questionnaire (DD Form 48) which includes questions concerning past or present membership in any organization on the Attorney General's list. If derogatory information concerning the employee is found by the service investigating group, he is given notice that he will be denied clearance and that he has the right to appeal the decision to the regional Industrial Security Board. These boards are usually staffed by officers of the service denying clearance. The standard for denying clearance is "that on all information the granting of such clearance is not clearly consistent with the interest of national security." ${ }^{178}$ Among the criteria to be considered is affiliation with or membership in "any foreign or domestic organization, association, movement, group or combination of persons [which is] totalitarian, fascist, communist, or subversive or [which has] adopted a policy of advocating or approving the commission of acts of force or violence to deny others their rights under the Constitution of the United States, or which seeks to alter the form of government of the United States by unconstitutional means."

The charges presented against the employees usually include past or present Inembership in or association with one or nore groups listed by the Attorney General. What weight is given to nembership is not apparent since the ultimate decision is inerely "clearance granted" or "clearance denied."78

70342 U.S. 485 (1952), 36 MINN. L. REv. 961, 100 U. PA. L. REv. 1244.

71341 U.S. 56 (1951). For discussion of this case see 37 A.B.A.J. 604 (1951).

72 Joint Anti-Fascist Refugee Committee v. McGrath, 341 U.S. 123, 137 (1951). See text at note 131 infra.

73 Industrial Personnel Security Review Regulation, 20 FED. REg. 1553 (1955).

74 Ibid.

75 Service Reg. 380-405-6; 32 C.F.R. $\$ \S 889.5$, 889.6 (1954).

T6 Service Reg. 380-405-6, III (14); 32 C.F.R. $\$ 889.5$ (1954).

77 Service Reg. 380-405-6, III (15) (4); 32 C.F.R. $\$ 889.6$ (1954).

78 See Yarmolthsky, Case Studies in Personnel Security, Case Nos. 5, 6, 11, 45 (1955). 


\section{The Port Security Program}

By Executive Order No. $10173,{ }^{79}$ issued under authority of the Magnuson Act, ${ }^{80}$ the President authorized the Coast Guard to conduct security checks on all waterfront employees and all seamen who are under United States jurisdiction. ${ }^{81}$ The Coast Guard has adopted regulations in compliance with this order for screening such employees. ${ }^{82}$ Under the order, clearance is denied "unless the Commandant is satisfied that the character and habits of life of the applicant are such as to authorize the belief that the presence of such individual on board a vessel or within a waterfront facility would not be inimical to the security of the United States." 83 The Commandant, in granting or denying clearance, will consider whether "reasonable grounds exist for belief that the individual": ${ }^{84}$

(5) is or recently has been a member of or affiliated with any foreign or domestic organization, association, movement, group or combination of persons (i) which is or which has been designated by the Attorney General totalitarian, fascist, communist, or subversive, (ii) which has adopted or which has been designated by the Attorney General as having adopted, a policy of advocating or approving the commission of acts of force or violence to deny other persons their rights under the Constitution of the United States, or (iii) which seeks or which has been designated by the Attorney General as seeking, to alter the form of the Government of the United States by unconstitutional means; provided That access may be granted notwithstanding such membership, affiliation or association, if it is demonstrated by more than a mere denial, that the security interests of the United States will not thereby be jeopardized.

The decision to deny clearance is appealable, and at the proceeding the individual has a right to introduce evidence in his favor. ${ }^{85}$ But since no detailed charges are made against hin in the initial proceeding, he actually has no way of knowing on what grounds clearance was denied. The Board need not disclose any derogatory information against the employee if this disclosure would be "inimical to national security."86

The recent case of Parker v. Lester 87 decided that a hearing which did not permit the employee to cross-examine testimony of persons submitting derogatory information was not compatible with an employee's right to due process of law. The court granted to an individual who had been denied clearance relief against the Coast Guard Commandant. Judge Pope, speaking for the ninth circuit court of appeals, pointed out that ${ }^{88}$

7933 C.F.R. pt. 6 (Supp. 1955).

8064 STAT. 1038 (1950), 50 U.S.C. $\$ 191$ (1952).

81 For an exhaustive report on the Port Security Program, see Brown \& Fassett, Security Tests for Maritime Workers: Due Process Under the Port Security Program, 62 YaLE L.J. 1163 (1953).

8233 C.F.R. $\$ \S 121.11-121.20$ (Supp. 1955).

8333 C.F.R. § 6.10-1 (Supp. 1955).

8433 C.F.R. $\$ 121.13$ (d) (Supp. 1955).

8533 C.F.R. \& 6.10-9 (Supp. 1955). The decision denying clearance is appealable to appeal boards set up by the Coast Guard Commandant. A board is made up of one Coast Guard officer, one representative from management and one from labor.

86 33 C.F.R. $\$ 121.23$ (Supp. 1955).

87227 F.2d 708 (9th Cir. 1955).

88 Id. at 717. Myers v. United States, 272 U.S. 52 (1926), as interpreted by Humphrey's Executor v. United States, 295 U.S. 602 (1935), held that the dismissal of an official performing "purely executive duties" was an executive perogative. Quaere: Since the official apparently was dismissed without even procedural safeguards, does the Myers decision imply that due process is not required?

In United Public Workers v. Mitchell, 330 U.S. 75 (1947), the Supreme Court held that dismissal from the Civil Service was not a "punishment" but a function of Congress and the 
[T] he liberty of appellees to follow their chosen employment is no doubt a right more clearly entitled to constitutional protection than the right of a government employee to obtain or retain his job [and that ${ }^{80}$ these regulations fall short of furnishing the minimum requirements of due process in respect to ... opportunity to be heard.

The Government has decided not to appeal this decision. ${ }^{00}$

\section{Independent Action by the Employer}

What is the right of a private employer to discharge an employee on the ground of suspected disloyalty to the Government of the United States? The common law, in the absence of contract, recognizes no prohibitions on the right of an employer to discharge any of his employees without cause. ${ }^{11}$ However, many states have passed legislation which restricts the employer's rights with regard to discharge of his employees. ${ }^{92}$ All cases decided thus far have held these statutes inapplicable to discharges for disloyalty ${ }^{93}$ and have upheld the right of the employer to interrogate his employees concerning their affiliation with groups on the Attorney General's hist. ${ }^{\text {44 }}$

In Lockheed Aircraft Corp. v. Superior Court ${ }^{95}$ the court held that the state statute which prohibited an employer from discharging an employee on the ground of political activity ${ }^{96}$ did not include a prohibition against discharge on the basis of the employer's dissatisfaction with the employee's loyalty. Under the National Labor Relations Act ${ }^{97}$ and the Taft-Hartley Act ${ }^{98}$ an employer may not discharge anyone in his employ for reasons related to union activity ${ }^{90}$ Prior to the Korean War the NLRB, although indicatimg that suspected disloyalty might be a ground for discharge, held that past or present membership in radical groups was not sufficient evidence of disloyalty. ${ }^{100}$ However, since that time the Board las been more sympathetic toward this conduct on the part of the employer where the employee has failed to sign an affidavit of past or present non-membership in designated organizations. ${ }^{101}$ By far the nost important restrictions on the employer's

Executive. In Umited States v. Lovett, 328 U.S. 303 (1946), the Court held that proscription from the federal employment for a set number of years or forever was a "punishment" and hence such proscription by Congress was a bill of attainder and improper. See Hannegan $v$. Esquire, Inc., 327 U.S. 146 (1946), and Frost and Frost Trucking Co. v. Railroad Comm'n, 271 U.S. 583 (1926), holding that Congress may not use the granting of a privilege as a method of denying any constitutional rights. Presumably this would include the right to due process. In Cole v. Young, 351 U.S. 536 (1956), the Supreme Court greatly restricted the operation of the loyalty-security program by interpreting the Act, 64 STAT. 476, 5 U.S.C. §§ 22-1, $22-3$, as applying only to employees holding "sensitive" positions in the government.

80227 F.2d at 724.

${ }^{00}$ San Francisco Chronicle, Apr. 1, 1956, § 1, p. 1, col. 5.

91 Odell v. Humble Oil and Refining Co., 201 F.2d 123 (10th Cir. 1953); Jefferson Eloc. Co. v. NLRB, 102 F.2d 949 (7th Cir. 1939).

92 CaL. Labor Code $\$ \$ 1735,1777.6$; IrI. Stat. ANN. \$§ 29-17-24, 29-24a-9 (1953); Ned. REv. STAT. § 48-215 (1950).

93 Santiago v. People of Puerto Rico, 154 F.2d 811 (1st Cir. 1946) and cases cited therein. 94 For a good discussion of these cases, see Comment, 28 LAB. REL. REP. 96 (1951). 9528 Cal. 2d 481, 171 P.2d 21 (1946).

96 CaI. LaBor Code § 1101-02.

9749 STAT. 449 (1935).

0861 STAT. 136 (1947), 29 U.S.C. \$§ 141-88 (1952).

9961 STAT. 136 (1947), 29 U.S.C. $\$ 158$ (a) (1952).

100 Franque A. Dickins, Engineer, 64 N.L.R.B. 797 (1945) ; The New York Times Company, 26 NL.R.B. 1094 (1940); see N.L.R.B. v. Fulton Bag and Carpet Mills, 180 F.2d 68 (10th Cir. 1950).

101 Administrative Ruling of NLRB General Counsel, Case No. 339 (July 11, 1952); Comment, 30 L.R.R.M. 1303 (1952). 
right to discharge an employee are contained in collective bargaining agreements. Most of these agreements provide that the employer must show reasonable grounds for discharge. ${ }^{102}$ Before 1950 most labor arbitration boards held that being a member of an organization on the Attorney General's list was not a "just cause" for discharge of an employee, ${ }^{103}$ but with the Korean conflict the attitude of the NLRB and the courts toward discharges by the employer for "disloyalty" has changed. ${ }^{104}$

\section{Housing}

In 1952 Congress passed the so-called "Gwinn Amendment"105 which provided that "no housing unit constructed under the United States Housing Act of 1937, as amended, ${ }^{106}$ shall be occupied by a person who is a member of an organization designated as subversive by the Attorney General." The court contest under this statute typically arises when the local housing authority institutes eviction proceedings against tenants who have refused to sign the non-membership affidavit. ${ }^{107}$ Most of the decisions which have demied eviction have done so on non-constitutional grounds, ${ }^{108}$ and those that have permitted eviction have held that the affidavit is a reasonable requirement for persons desirmg to live in housing projects which are made available, in part, by federal funds. ${ }^{109}$ However, in Lawson v. Housing Authority of Milwaukee ${ }^{110}$ the Supreme Court of Wisconsin held that possible harm from the suppression of the freedoms gnaranteed by the first annendment outweighed any threatened evil posed by occupation of federally aided housing projects by past or present members of subversive organizations. Whether the list was a valid criterion for denying housing was not discussed. ${ }^{111}$ There has been no test of the Gwinn Amendment in the United States Supreme Court.

\section{Deportation}

The Immigration and Nationality Act of $1952^{112}$ provides that any alien who is or who has ever been a member of the Communist Party or any "totahtarian" organization ${ }^{113}$ or who is or has ever been a member of an organization which

102 Chamberint, Coltective Bargaining 84 (1951).

10313 Lab. ARB. 848 (1949); 9 LAB. ARB. 749 (1947).

104 See, e.g., Black v. Cutter Laboratories, 43 Cal. 2d 788, 278 P.2d 905 (1955); 19 LAB. ARB. 40 (1952).

10566 STAT. 403 (1950), 42 U.S.C. $\$ 1411$ (c) (1952).

10650 STaT. 888 (1937), 42 U.S.C. $\$ 1401-33$ (1952).

107 For an excellent discussion of the housing situation in regard to the security programs see Note, Denial of Federally Aided Housing to Members of Organizations on the Attorney General's List, 69 HaRv. L. REv. 551 (1956).

108 Rudder v. United States, 226 F.2d 51 (D.C. Cir. 1955) (holding that action was "arbitrary," but not ruling on constitutionality of the Gwinn amendment); Chicago Housing Authority v. Blackman, 4 Ill. 2d 319, 122 N.E.2d 522 (1954) (action must have some relation to the statutory purpose).

109 Weixel v. New York Housing Authority, 208 Misc. 246, 143 N.Y.S.2d 589 (1955).

110270 Wis. 269,70 N.W.2d 605 (1955).

111 In United States v. Remington, 191 F.2d 246 (2d Cir. 1951), the conviction of the defendant was reversed partly because the prosecutor was permitted to make numerous references to defendant's membership in organizations on the Attorney General's list. Judge Swan stated, "This was error, for the list is purely hearsay declaration by the Attorney General .... It has no competency to prove the subversive character of the listed associations and, failing that, it could have no conceivable tendency to prove the defendant's alleged perjury even if it were shown that he belonged to some or all of the organizations listed." Id. at 252 .

11266 STAT. 163 (1952), 8 U.S.C. $\$ \$ 1101-503$ (1952).

11366 STAT. 163 (1952), 8 U.S.C. \$1251(a) (6)(C) (1952). 
advocates the overthrow of the Government of the United States by force or violence ${ }^{114}$ shall be deported. The act provides for a hearing officer who conducts the hearing and who makes the determination. ${ }^{115} \mathrm{By}$ virtue of this act, membership in the Communist Party is conclusive with regard to the alien's advocacy of these beliefs. ${ }^{116}$ Whether past or present membership in organizations other than the Communist Party is determinative of the holding of such beliefs is a question of fact for the hearing officer whose deportation order is final unless appealed. ${ }^{117}$

\section{Armed Forces Security Program}

Every service inductee, reservist, or person on active duty is required to ezecute Department of Defense Form $98 .{ }^{118}$ This form contains a list of the organizations cited by the Attorney General. All personnel are required to state any affiliation they might have had with these organizations. The Departments of the Army ${ }^{110}$ and of the Air Force ${ }^{120}$ have published regulations with regard to deterinination of adverse reports based on form DD 98 . Both regulations specifically refer to affiliations with organizations listed by the Attorney General as a criterion ${ }^{121}$ for determining whether "the appoimtment, enlistment, voluntary call to active duty, or retention in a regular duty status is clearly consistent with the interests of national security."122

The personnel study made by Yarmolinsky indicates that a majority of the charges against servicemen consist of membership in or affiliation with these groups either by the serviceman himself or one of his friends or relatives. ${ }^{123}$ The burden of proof is on the soldier to rebut or refute the allegations. ${ }^{124}$ In case of an adverse finding the person inust be given a "less than honorable" discharge. These types of discharges range from "general" to "undesirable."125

A Department of the Army letter dated October 1955 instructed the Field Boards of Investigations that when considering a "security risk" case they should consider ameliorating factors such as the serviceman's age at the time of association, the length of time of membership, and the man's knowledge concerning the nature and objectives of the group. ${ }^{126}$ In a recent federal district court decision it was held that an honorable discharge was a property right, and further that ${ }^{127}$

11466 STAT. 163 (1952), 8 U.S.C. § 1251(a) (6)(F) (1952).

11566 STAT. 163 (1952), 8 U.S.C. \$ 1252 (1952).

11666 STAT. 163 (1952), 8 U.S.C. $\$ 1182$ (1952). See also In the Matter C-_ File E-131734, Bd. of Immigration Appeals, July 23, 1954, released Aug. 12, 1954. In Galvan v. Press, 347 U.S. 522, 529 (1954), the Supreme Court refused to consider whether membership in the Communist Party itself showed personal advocacy of its doctrines, holding that Congress's intention was clear.

1178 C.F.R. § 241.6 (Supp. 1955).

118 Dep't of Defense Directive No. 52109, Apr. 7, 1954.

119 Army Reg. 604-10.

12032 C.F.R. $\$ 866$ (1954).

121 Army Reg. 604-10, par. 13(b) (6); 32 C.F.R. \& 866.5(c)(4) (1954).

122 Army Reg. 604-10, par. 12.

123 Yarmolinsky, Case Studies in Personnet Security, Case Nos. 101, 108 (1955).

124 Service Reg. 605-200-1, par. 4(f) (21).

125 Army Reg. 604-10, par. 1. A less-than-honorable discharge deprives veterans of Federal Civil Service priority, 62 STaT. 1017 (1948), 5 U.S.C. \& 851 (1952); their right to musteringout pay, 58 STAT. 10 (1944), 38 U.S.C. $\$ 691$ (a) (1952) ; and they lose their right to re-employment, 62 StaT. 914 (1948), 50 U.S.C. App. § 459(h) (1952).

126 Faulkner, Security Program in the Armed Forces, 15 Law. Gumb REv. 145, 147 (1955). 127 Bernstein v. Herren, 136 F. Supp. 493, 501 (S.D.N.Y. 1955). 
[I]f an honorable discharge were denied to a soldier with an unexceptionable service record, on the basis merely of pre-induction conduct it would in my opinion be a deprivation of property without due process of law, and a regulation establishing a procedure for effecting such a denial could not be authorized by statute.

Prior to this decision the Defense Department had announced that in the future all security investigations would be made before the person was inducted and all future discharges would be made solely on the basis of the individual service record, but no announcement was made concerning cases already pending. ${ }^{128}$

\section{CONCLUSION}

If a person remains a member of an organization after it has been cited, that fact seems potentially disastrous im the areas in which the list is used. Yarmolinsky cites no cases in which a present member has been given a security clearance. ${ }^{129}$

The effect of past membership in a designated organization is difficult to evaluate. Yarmolinsky cites many cases in which past members lave been cleared of any suspected disloyalty, but also just as many cases in which clearance has been denied. The basis for clearance or non-clearance is not divulged, hence any weight which might have been attached to other factors, such as scienter, is impossible to ascertain. However, it can be categorically stated that past membership is sufficient basis for the presenting of the charge. Presumably, at the liearing the circumstances surrounding the membership are weighed to determine wliat effect the past associations will have in the final determination. What weight is assigned to either the past membership or the surrounding circumstances cannot be calculated.

Merely being charged with or suspected of disloyalty in these tense times is a liarrowing experience. Yet past or present membership in an organization listed by the Attorney General is often the only basis for the charge of disloyalty. ${ }^{130}$ Even assuming that an individual is eventually cleared of the charge, the blot on his record may be hard to expunge. Inasmuch as the list is so widely used with such serious consequence the potential danger of an impeachable compilation is clearly apparent. It would seem that the present list may be challenged both as to its substance and as to the method by which it was compiled.

In Joint Anti-Fascist Refugee Committee v. McGrath Justices Burton and Douglas, delivering the judgment of the Court, declared that the action of the Attorney General in listing the organizations without any form of hearing was "patently arbitrary."131 Justice Black, in his concurring opinion, stated that "the methods employed by the Attorney General exceed his authority ... " and that "the Due Process Clause of the Fifth Amendment would bar sucl condemnation without notice and a fair hearing." 132 Justice Frankfurter, in another opinion, said that "the wholly summary process for the organizations is inadequate." Justice Jackson declared that he would reverse the decision "for lack of due process in denying a hearing at any stage."134 Despite the Joint Anti-Fascist case the Attor-

128 Faulkner, Security Program in the Armed Forces, 15 LAw. Gund Rev. 145, 151 (1955).

129 Yarafortnsky, Case Studies in Personnex Security (1955). Compare Case Nos. 40, $49,51,53,64,175$, in which the individual was charged with being presently a menber and where clearance was denied, with Case Nos. 59, 88, 108, 136, 190,244, in which the charges were seemingly more substantial and serious but clearance was granted.

130 Yarafolinsky, Case Studies in Personnel Security, Case Nos. 40, 49, 53 (1955).

131 Joint Anti-Fascist Refugee Coununittee v. McGrath, 341 U.S. 123, 137 (1951).

132 Id. at 143 .

133 Id. at 173.

134 Id. at 187 . 
ney General under Executive Order No. $10450^{135}$ (published two years after that case) redesignated all groups which had been previously designated under Executive Order No. $9835^{136}$ without affording them any liearing. It is true that the groups now have a right to a hearing after their designation. ${ }^{137}$ However, at least four justices were in agreement that merely being listed was of substantial damage to the organizations themselves ${ }^{138}$ and a fifth stated that even if the groups were not themselves damaged they had standing to protest the designation to protect the rights of their members. ${ }^{139}$ At the present time no hearing in any form has been granted to any of the organizations on the list. It would appear then, that all of these groups have been designated in defiance of a ruling by the Supreme Court. However, even assuming that the Attorney General were to conform to the Court edict, the practices of listing defunct organizations and of consolidation of the list into an alphabetical roster rather than in distinct categories seem to be incorrect.

The fact that an organization is defunct precludes any possibility of its conforming to the Attorney General's regulations and it is thus precluded from ever contradicting the Attorney General's findings as to its character. ${ }^{140}$ Whether or not the organization itself is damaged by the listing, ${ }^{141}$ there can be no doubt that former members are potentially harmed. Yet present security procedures apparently preclude the investigation by the hearing officer of the character of any group designated by the Attorney General. ${ }^{142}$ In essence then, a former member of one of these organizations must concede the strength of this evidence and attempt to rebut it affirmatively by introduction of other evidence.

The decision by the Attorney General to discontinue the categorization would seem to restrict whatever value the list might otherwise have in many areas where it is now being used. Many state and federal statutes proscribe membership in subversive organizations ${ }^{143}$ or in groups which advocate the overthrow of the

13518 FED. REg. 2489 (1953).

13612 FED. REG. 1935 (1947).

13728 C.F.R. $\$ 41.11$ (Supp. 1955).

138 Justices Burton and Douglas in Joint Anti-Fascist Refugee Committee v. McGrath, 341 U.S. 123, 139 (1951), stated that the effect of listing " . . . is to cripple the functioning and damage the reputation of those organizations in their respective community and in the nation. The complainants, sufficiently charge that such acts violate each complaining organization's common law right to be free from defamation." Justice Black at 143 states, "Petitioners ... have a right to conduct their admittedly legitimate pohitical, charitable and business operations free from unjustified governmental defamation." Justice Frankfurter declared at 159, "Designation works an immediate substantial harm to the reputation of petitioners."

139 Justice Jackson, although questioning the fact of damage to the organizations themselves, declared that the organizations should have a right to contest the designation because of the harm which would come to its members. 341 U.S. 184-86.

140 See note 30 supra.

141 See Bontecou, The Federad Loyazty-Security Program 177 (1953), for a list of organizations which have been denied tax exemptions largely on the basis of the list. See also the Treasury Department Press Release which indicated that the basis for the withdrawal of the exemption was the designation by the Attorney General. 5 CCH FED. TAX REP. 6075 (1948). 142 See the Loyalty Review Board Memorándum No. 2, issued March 9, 1948. "Boards ... . should not enter upon any evidential investigation of the nature of any of the organizations identified in the Attorney General's list, for the purpose of attacking, contradicting, or modifying the controlling conclusion reached by the Attorney General in such list . . . . The Board should permit no evidence or argument before it on the point." Apparently the Boards havo been following this instruction. Yararormsskx, Case Studies IN Persomner Security 43 (1955), records the following statement made by a hearing officer in October, 1952: "This Board has no authority to question the decision of the Attorney General."

143 See note 42 supra. 
Government by force and violence. ${ }^{144}$ Since these comprise only two of the six criteria which the Attorney General was instructed to use in determining the organizations to be designated, ${ }^{145}$ any use of the list by officials administering these programs is immediately open to objection. In addition, since the consolidation the list commonly has become known as the "subversive list," and being or laving been a member of one of the groups is generally equated to the lolding of subversive beliefs.

All indications would seem to point to the necessity of a re-evaluation of the need for and the scope of any publication of a hist of organizations by the Executive, inembership in which may be evidence of disloyalty to the Government. As has been seen, the publication of such a list has wide and serious consequences far beyond the area in which it was originally intended to operate. An Attorney General's hist, properly broken down into carefully described categories and compiled after a full and fair hearing to the groups involved, might be useful for certain purposes such as einployment in "sensitive" governmental positions. However, it is submitted that the list as presently constituted and coinpiled should be withdrawn.

Donald L. King

144 See note 43 supra.

145 Exec. Order No. 9835, pt. III (3), 13 FED. REg. 1935 (1947). 